\title{
The Implementation of Professional Competence in Teaching ESP at Four Private Vocational Schools in Grobogan
}

\author{
Eva Rahmatunnisa ${ }^{\bowtie}$, Januarius Mujiyanto, Dwi Anggani Linggar Bharati \\ Universitas Negeri Semarang, Indonesia
}

\begin{abstract}
Article Info
Article History:

Recived 24 December

2020

Accepted 03 February

2021

Published 20 June

2021

Keywords:

Professional

competence, ESP,

Private vocational high school.

Abstract

A Professional teacher should master some competencies; one of them is professional competence. Accordingly, the preliminary research showed that some teachers had problems in the teaching-learning process. This research aimed to analyze the teachers' competence in designing the syllabus, creating the lesson plan, developing the learning material, applying the learning media, the teachinglearning process, and constructing the students' assessment. This study was a qualitative case study. Subjects of the study were four private vocational school teachers in Grobogan. The data were collected by implementing observation, document analysis, and interviews. There were three steps in analyzing data, such as identifying, analyzing, and interpreting. The result showed that all teachers were good at designing ESP syllabus according to the instructional material, learning activity, assessment, time allocation, and learning resources. Then, they had created an ESP lesson plan well even though a teacher missed writing the learning method and the learning media. The media used were such as whiteboard, board markers, LCD, laptop, and other supporting materials. Additionally, all teachers did the teaching- learning process well despite some teachers found difficulties in applying lesson plan, they could not associate the lesson plan with the real condition in the class. The last finding showed that all teachers made an individual assignment for their students. But there was only a teacher who made group assignments. This research is expected to contribute to the teachers or lecturers in implementing professional competence to teach ESP.
\end{abstract}




\section{INTRODUCTION}

English for Specific Purposes (ESP) is English designed for specific disciplines. ESP may use in specific teaching situations and different methodology from general English. However, ESP is likely to be designed for adult learners, either at a tertiary level in an institution or in a professional work situation. According to Basturkmen, H (2010, p. 3), ESP courses are narrower in focus than general ELT courses because they centre on analysis of learners' need. The statement showed that ESP views learners in terms of their work or study roles and that ESP courses focus on work or study-related needs, not personal needs or general interests.

Indonesia is one of the countries that has also been developing ESP projects in vocational schools, academies, and universities. In vocational high school, the students are prepared to be ready to work after graduating. Vocational school students focused on practices rather than the theory. So, teaching ESP in vocational school is not easy to do, and it has many challenges. It needs not only good knowledge and skills but also a lot of preparation and creativity.

To develop Indonesian teachers' competencies, the government made the teacher competency standard that should be mastered by all teachers. According to Peraturan Menteri Pendidikan Nasional number 16 the year 2007, there are four competencies: pedagogic, personal, social, and professional competence. Unfortunately, ESP teachers may face some problems. When the researcher conducted the preliminary research, the result showed that a teacher mastered the material, but he did not develop the learning material to teach the students. It could be seen when a teacher taught the students only to use the textbook without explaining the material in detail. Besides, the preliminary research showed that a teacher did not use creative teaching techniques to teach the students. A teacher only taught the students monotonously. He did not use some strategies and methods of learning. Furthermore, a teacher lacked of technology. A teacher only focused on theory rather than practice. Because of that, some students felt bored and sleepy.

To minimize the problems, ESP teachers must have some competencies. Therefore, ESP teachers can teach the students professionally and creatively. Mulyasa (2013, p. 26) stated that competence is knowledge, skills, and abilities or capabilities that a person achieves, which become part of their being to the extent they can satisfactorily perform particular cognitive, affective, and psychomotor behaviors. Therefore, competence is knowledge, skills, and behavior that enable someone to do something well.

There were some numerous studies conducted related to those issues, such as Priyogo et al. (2013), the findings showed that the redesigning syllabus employs systematic procedures including current syllabus, students' needs, and institution policy that were needed to be considered in determining syllabus components. In creating the lesson plan, Rambe (2016) found that the English lesson plan in vocational school is designed based on consideration of some parameters including competence, goals, objective, time allocated, method, learning material, source of material, and assessment. The English lesson plan designed by teachers has similarities and differences between one with others.

In creating lesson plan, Ekawati (2017) showed her findings that three teachers do not prepare lesson plan before their teaching learning process, all teachers understand the principles of scientific approach and the basic concept of 2013 curriculum. But they do not apply it in their teaching, one teacher prepares the teaching media but the others do not prepare it, and all teachers get difficulties in assessing students' attitude (behaviour). Moreover, Marliani, B. (2017) showed the result that there were problems faced by the English teacher in designing lesson plan as follows: (1) the teacher faced problem in determining learning method, (2) the teacher faced problem in determining learning media, (3) the teacher faced problem in looking for learning sources.

In developing learning material, some researches were also conducted by some experts. 
Navarro (2015) concluded that participants' insights, comprehension, conidence, and autonomy will vary, depending on their educational phase and experiences, but all of them have benefited from the purpose of designing EFL teaching materials and have seen its challenges as a resource for professional growth. Moreover, a study was conducted by Trisyanti (2009). She explained that materials should match learner needs and wants, and principles of language learning. They should be developed in ways which provide flexibility of use as well as coherence of connection.

However, for developing the learning materials, Rahmi (2014) found that $90 \%$ of the students like to study English by using media. So, it is suggested that English teachers should use the media because they are useful tools in the English teaching-learning process. To strengthen the data, other study was conducted by the study was from Sudartini et al. (2016). The study reveals that there is not any English textbook that fits the learning needs of these particular learners, teachers are supposed to use the same book as those for the common senior high schools. Consequently, they also find their own materials to fit the learners' needs from many different sources.

In the teaching-learning process, a study was conducted by Taridi (2016) researched the teaching-learning process following the 2013 Indonesian curriculum. The findings describe the analysis of the teaching and learning process's implementation, classified into three themes (introductory, core, and closing activities).

The teacher should implement professional competence in creating the students' assessment. Efendi (2017) found that the implementation portfolio assessment improves students' writing skills. Therefore, the hypotheses of this study were accepted. There was a significant improvement in students' writing skills by using portfolio assessment. Rahmat (2010) showed that comprehensive assessment plan to ensure all courses and program outcomes are properly assessed. Besides, the plan will motivate the students to focus their learning activities towards the achievement all learning outcomes.
This study attempts to implement professional competence in teaching English for Specific Purposes at Four Private Vocational Schools in Grobogan. The researcher chooses those objects because most of the students around the researcher's place cannot go to State Vocational Schools. It takes more than an hour to get there. Also, most of the Vocational Schools in Gubug are private schools.

\section{METHODS}

Typically, this research was designed as a descriptive qualitative case study. This study focused on analyzing the teacher competence in designing the syllabus, creating the lesson plan, developing learning material, applying learning media, teaching-learning process, and constructing students' assessment.

This research involved four ESP teachers. The schools chosen were SMK Miftakhul Huda Ngroto, SMK Nusantara Gubug, SMK Muhammadiyah Gubug, and SMK Bina Negara Gubug. The main object of this study was professional competence.

Instruments of collecting the data in this research were document analysis, observation, and interview. Firstly, the data gathered from the teaching document were the syllabus and lesson plan. After that, the researcher did the classroom observation to analyze developing learning material, applying the learning media, and teaching the learning process.

To make the analysis more manageable, there are four codes for analyzing the data such as:

Table. 1 The code for analyzing the data

\begin{tabular}{lc}
\hline Code & Teacher \\
\hline T1 & SMK MuhammadiyahGubug \\
T2 & SMK Nusantara Gubug \\
T3 & SMK Miftahul Huda Ngroto \\
T4 & SMK Bina Negara Gubug \\
\hline
\end{tabular}




\section{RESULTS AND DISCUSSION}

This section presents six findings of the study. Those findings were explained below:

\section{The implementation of teachers' competence in designing ESP syllabus}

To determine the teachers' competence in designing the syllabus, the researcher gathered the data by analyzing the teaching document, especially the syllabus, from four teachers. There were components analyzed in this finding, such as instructional material, learning activity assessment, time allocation, and learning resources. The finding of the data showed that all instructional materials supported the achievement of basic competence. Furthermore, they were relevant to the core competence and basic competence. However, the materials were consistent, and they were under time allocation.

In learning activities, all syllabuses were student-centered. Moreover, all stages of learning activities supported the achievement of basic competence. Additionally, they allowed students to develop 4C (creativity, critical thinking, communication, and collaboration). Other findings were found in both assessment and time allocation. All teachers' assessments were done based on indicators and adjusted to the learning experience. Hereinafter, these were done using test and non-test, both written and oral, according to their competencies. The finding also showed that all assessments carried out to measure competencies by using reference criteria.

Further, the time allocation was under the breadth and depth of material. The last was learning resources. There were several learning resources in all syllabuses. They were under learning material.

A syllabus is a document that is used as the guideline for the teacher and students in the teaching and learning process to achieve the goals, according to Hutchinson and Waters (2002, p. 80). He defines syllabus as "a document which says what will (or at least what should) be learned." Regarding the implementation of teachers' competence in designing the syllabus, all teachers have designed a good syllabus according to the instructional material, learning activity, assessment, time allocation, and learning resources. This is not in line with Rusmawan (2016). In this research, he found that most of the syllabus is not ideal; most of the syllabus does not use active verbs in $\mathrm{KD}$ and indicator. It means that most of the teachers are still challenging to identify $\mathrm{KD}$ and indicators.

\section{The implementation of teachers' competence in creating a lesson plan}

The lesson plan designed by teachers was used as the guide to do TLP in the classroom. This part was elaborated the lesson plans' component. As stated in Salinan permendikbud number 12 years 2016, there are thirteen components in creating a lesson plan. The components analyzed as follows school identity, main material, time allocation, learning purpose, basic competence and indicator of competence achievement, learning materials, learning methods, learning media, learning sources, learning steps, and assessing the learning process.

According to the findings, all teachers had created school identity, primary material, time allocation, learning purpose, basic competence, and indicator of competence achievement, learning materials, learning sources, and assessing the syllabus optimally's learning process. They created the lesson plan following the primary material. They might be had a different lesson plan from one to others. Unfortunately, the researcher found that $\mathrm{T} 3 \mathrm{did}$ not create a learning method, and T4 did not create learning media. Here was the table of the analysis.

Based on the lesson plan elements, the finding showed that most teachers created the lesson plan well. This is in line with Rambe (2016). He found that vocational school's English lesson plan is designed based on considering some parameters including competence, goals, objective, time allocated, method, learning material, source of material, and assessment. Moreover, it is also not in line with Suroyo \& Faridi (2018). Their finding of developing speaking English for specific purposes materials for primary broadcasting students showed that 
some English speaking materials for vocational students were not in the form of ESP materials.

Besides, According to the finding, this is in line with Bharati (2010, p. 95). In her finding, it showed that a lesson plan should consist of: the identity of the school, the identity of the lesson, gare/ semester, time allocation, standard of competence, basic competence, objectives, material, method, learning activities, source, homework, indicators, a set of evaluation, and rubrics of evaluation.

\section{The implementation of teachers' competence in developing learning material}

From the classroom observation, the researcher found that all ESP teachers choose the appropriate materials according to the students' development level. As mentioned in the previous finding, $\mathrm{T} 1$ and $\mathrm{T} 2$ might have the same topic: asking and giving direction. In contrast, T3 and T4 were about the degree of comparison.

In developing learning material, most teachers could manage the learning material creatively. The students were active during the teaching-learning process. In contrast, T3 did not manage the class because some students were not active and sleepy. Additionally, she also did not develop the lesson plan well.

Other results showed that no ESP teachers used the language laboratory or library in the teaching-learning process. On the other hand, T1, $\mathrm{T} 2$, and T4 taught the material clearly to understand. However, the researcher found that T3 did not do that because she taught the material monotonously.

Ideally, English teachers must have some competencies to apply the curriculum. Harmer (1998) stated that English teachers should develop and adapt the materials based on their needs and ability by modifying and extending the content and task to support this idea.

The current study showed that some teachers were good at developing the learning material. They used some techniques in the teaching-learning process. They chose the appropriate materials according to the level of the students' development. Besides, they were also able to manage the class well and use the internet.
This conformed to the previous study of developing learning material conducted by Satriani, I. (2014). Based on the finding, it indicates that preparation in using English textbooks is essential for the teachers to be creative in developing the materials, to be able to use authentic and commercial materials besides textbooks, and give many benefits both for the students and for the teachers. Those materials are quickly taken from the environment and the internet.

\section{The implementation of teachers' competence in applying the media to teach ESP}

The teacher might use useful and exciting media to make the students understand the material quickly. According to the findings of the classroom observation and interview session, the results showed that all teachers applied teaching methods such as T1 used audio-lingual method and group discussion, T2 used discovery learning, audio-lingual method, and drilling technique, T3 used drilling technique, and T4 used number head together (NHT), drilling technique, and discovery learning.

To strengthen the data, the researcher observed the use of learning media. She found that most teachers used variety in learning media, for instance: video, PPT, textbook, Google maps, whiteboard, board marker, laptop, and sound. Yet, only a teacher used a textbook without adding another media while teaching. She did not teach the students creatively by using the media. Additionally, all teachers used handouts as the primary source.

In applying learning media, some teachers used dictionary to check the spelling, for example: "direction", "left", "signpost", "traffic light", etc. Accordingly, T1 and T4 used IT during the teaching-learning process. T1 used a laptop for applying the video and showing PPT. Additionally, T4 used a laptop to seek additional information. In contrast, T2 and T3 did not use IT in TLP.

Another finding was from the interview session. There were five questions conducted by the researcher. The findings showed that all teachers agreed that learning media was 
significant because it could motivate them to learn English. Then, all teachers had ever applied learning media such as scrabble, flashcards, whiteboard, laptop, sound, videos, pictures, quizzes, audio, books, worksheet, etc. To achieve the learning goal quickly, teachers should optimize the learning media. Unfortunately, not all teachers had optimized it. The reason was they did not have enough time to develop the learning media.

To strengthen the data, the researcher asked the teachers about difficulties in applying the learning media. The results showed that the schools were lack of facilitation such as LCD, projector, and internet access. Additionally, a teacher also was demanding in managing time. To overcome the difficulties, T1, T2, and T3 looked for other ways to teach them. Accordingly, T4 shared the problem with other teachers to get the solution.

The teachers use media in TLP to help the students get or understand the lesson easier. The media are also being used to send messages to the students and stimulate them to learn. The current study showed that some ESP teachers used media. This is in line with Rahmi (2014). In her finding, she found that $90 \%$ of the students like to study English using media. Additionally, this is in line with Septiana, E., Mujiyanto, J., \& Sutopo, J. (2020). The results showed that two English teachers' positive perceptions of using the Super Minds textbook reflected their planning, actual implementation, and evaluation in the classroom. Additionally, According to Hadijah (2016), the finding showed that the teachers are challenged to be able to deploy the video effectively due to numerous types of video that can be found and presented in the classrooms.

\section{The implementation of teachers' competence in the teaching-learning process}

The teaching-learning process includes implementing a lesson plan that includes preliminary activities, core activities, and closing activities.

In preliminary activities, all teachers pay attention to the students before the lesson. Additionally, they also provided a stimulus to the students, which lead to the material that would be discussed. After providing a stimulus to the students, all teachers also conveyed learning objectives. The learning objectives were the same as the lesson plan created by the teachers.

In core activities, all teachers mastered the subject matter according to the learning objective. They linked the material with other relevant knowledge, developments in science and technology, and real life. Moreover, all teachers utilized learning resources such as Forward Grade X Book Unit 5 by Erlangga. Then, they also used the internet and books as references. It had been explained in the previous finding.

Furthermore, T1, T2, and T4 could engage the students in TLP. The students were active and enthusiastic in joining the class. But, T3 could not engage the students because the students were passive in class. In this case, they felt sleepy because the teacher taught them like teachercentered. In core activities, all teachers carried out the learning assessment. The detailed information would be explained in the last findings of the research.

In closing activities, all teachers summarized the subject matter. They also guided the students to reflect on their learning. On the other hand, T1, T2, T3, and T4 gave feedback to students on learning outcomes. They provided follow-up activities in the form of assignments, both individual and group. Last, all teachers informed the plan of learning activities for the next meeting.

The teaching-learning process is a process that includes many variables. These variables interact as learners work toward their goals and incorporate new knowledge, behaviours, and skills that add to their range of learning experience. Brown (1987, p. 7) also states that teaching guides and facilitates learning, enables the learner to learn, and sets the condition for learning. Based on the lesson plan elements, all teachers did the teaching and learning process so that teaching and learning went smoothly from one activity to another. Even though some teachers found difficulties in applying the lesson plan, they could not associate the lesson plan with the class's real condition. Taridi (2016) supported 
the finding of the research. He researched the teaching-learning process following the 2013 Indonesian curriculum. The findings describe the analysis of the teaching and learning process's implementation, which are classified into three themes (introductory, core, and closing activities).

Moreover, this research is also in line with Dwi \& Syafri (2018). The result shows that the teacher can conduct the lesson plan and teaching media carefully. Besides, the teacher needs more time to prepare her lesson plans and teaching media; and some students may feel depressed because of the observers' attendance.

\section{The implementation of teachers' competence in} constructing the students' assessment

In this part, the researcher researched using a lesson plan document. The first point of the analysis was about preparing questions following the subject matter. As the researcher found, all ESP teachers had already made the questions according to the subject matter at the end of the lesson plan.

After making the questions, the teacher also made the answer key to the assignment. According to the finding, T1 made five answer keys based on the questions. Then, $\mathrm{T} 2$ also made five answer keys to the multiple-choice questions. Unfortunately, T3 and T4 did not make the answer key to the assignment. Other findings were from teachers' competence in preparing individual assignments and group assignments for the students. As the analysis above, all ESP teachers had already prepared the students' assignment. After getting the material, the students were given the assignment by the teachers. Besides ESP, teachers also prepared a group assignment. Unfortunately, not all ESP teachers made the assignment for group assignment. Only $\mathrm{T} 2$ prepares the group assignment. The detailed assignment was explained clearly. The last finding was about teachers' competence in preparing a grading system that would be used to assess student work. The researcher found that all ESP teachers have a grading system.
The last discussion is about constructing the students' assessment. Assessment is an important part in teaching. It is usually placed in the end of lesson plan. According to Brown (2004, p. 145) the term assessment is the activities during teaching and learning that not only in form of written test but also the oral questions from the teachers. It can be spontaneous questions for the teachers. Based on the finding, all ESP teachers made the individual assignment for their students. Unfortunately, only a teacher made group assignment. Efendi (2017) supported the finding of the research. He found that the implementation portfolio assessment improves students' writing skills. Additionally, Deluca et al. (2017) conducted the research about student perspectives on assessment for learning. This study highlights that assessment for learning implementation requires sustained focus, research, and support in schools and classrooms for students to value and fully benefit from assessment-based teaching.

\section{CONCLUSION}

The result of this study may lead to other studies. An in-depth study to analyze the professional competence could be conducted. It would also be better for future researchers to conduct a similar study with a wider scale and longer time to collect more complete information on how the teacher implements their competencies in the class.

This study was useful as a reference for the teachers or lecturers in implementing professional competence to teach ESP. This research is hoped to be worthy of English teachers' attention especially in designing the syllabus, creating the lesson plan, developing the learning material, applying the learning media, teaching-learning process, and constructing the students' assessment. 


\section{REFERENCES}

Basturkmen, H. 2010. Developing Courses in English for Specific Purposes. Palgrave Macmillan.

Bharati, D. A. L. (2010). Teachers' professional development through observation in immersion classes based on the documents and teaching and learning process. Language Circle Journal of Language and Literature, 4(2), 91-101.

Brown, H. D. (1987). Principles of language learning and teaching (2nd ed.). Englewood Cliffs.

Brown, H. D. (2004). Language assessment: Principles and classroom practices. Pearson Education.

Deluca, C., Valiquette, A., Coombs, A., McEwan, D. L., \& Luhanga, U. (2018). Teachers' approaches to classroom assessment: a large-scale survey. Assessment in Educational: Principles, Policy, \& Practice. 25(4). 355-375.

Depdiknas. (2007). Peraturan Menteri Pendidikan Nasional Nomor 16 Tahun 2007, Standar Kualifikasi Akademik dan Kompetensi Guru. Retrieved June 10, 2019,

Dwi Areni, G., K., \& Syafri, F. (2018). Enhancing teachers' professionalism and students' learning outcomes through lesson study. 12(2). 203-212.

Efendi, Z. (2017). Improving students' ability in writing English teaching by using portfolio assessment (An experimental study at SMKN 1 Blangpidie). Getsempena English Education Journal, 4(2), 152-163.

Ekawati, Y., N. (2017). English teachers' problems in applying the 2013 curriculum. 6(1). 41-48.

Hadijah, S. (2016). Teaching by using video: ways to make it more meaningful in EFL classrooms. 5(2). 307-315.

Harmer, J. (1998). How to teach English (1st ed.). Longman.

Hutchinson, T., \& Water, A. (1987). English for specific purposes: A learning-centered approach (13th ed.). Cambridge

University Press.

Mackay, R., \& Mountford, A. (1978). English for Specific Purposes: A case study approach. Longman.

Marliani, B. (2017). The problem faced by the English teacher in designing lesson plan at SMA Muhammadiyah 3 Batu. [Master's thesis, Universitas Muhammadiyah Malang]. Eprints Umm.

Mulyasa, E. (2013). Kurikulum Berbasis Kompetensi: Konsep, Karakeristik, danImplementasi. Remaja Rosda karya.

Navarro. (2015). The design of teaching materials as a tool in EFL teacher education: experiences of a Brazilian teacher education program. Scielo Journal, 68(1), 121-137.

Priyogo, A., Rukmini, D., \& Bharati, D. A. L. (2013). Redesigning general English syllabus for an intensive language program. English Educational Journal, 32), 78-84.

Rahmat, R. A., Osman, K., \& Basri, H. (2011). Achievement of Program outcomes using assessment plan. Procedia-Social and Behavioral Sciences. 18. 87-93.

Rahmi., R. (2014). The implementation of media in English language teaching. Visipena Journal. 5(1). 1-17.

Rambe., S., L. (2016). Designs of English lesson plan in the vocational school. English Education Journal, 4(1). 1-15.

Rusmawan, P., N. (2016). The formulation of indicator in teaching speaking skill. Jurnal Dimensi Pendidikan dan Pembelajaran, 4(2), 43-51.

Satriani, I. (2014). The analysis of teachers' preparation in using English textbook. The 61st TEFLIN International Conference. 288-290.

Septiana, E., Mujiyanto, J., \& Sutopo, J. (2020). Teachers' perception, plan, implementation, and evaluation toward using Super Minds textbook in EFL classroom. 10(3). 321-330.

Sudartini, S., Karmadi, S., \& Diyanti, Y. (2016). English teaching materials for SMK 
majoring in arts: teachers' perspectives. Proceeding the $2^{\text {nd }}$ International Conference on Teacher Training and Education, 2(1), 882-889. Retrieved from Suroyo., \& Faridi, A. (2018). Developing speaking English for specific purposes materials for broadcasting primary students - The case of an eleventh grade of vocational high school 1 Kendal. English Education Journal, 8(3), 324-330.
Taridi, M. (2016). English teaching and learning process analysis following the 2013 Indonesian curriculum. International Journal of Education Research, 1(1), 1016.

Trisyanti, U. (2009). Developing materials for ESP (English for specific purposes) class. Jurnal Sosial Humaniora, 2(1), 66-77. 